The magazine is free to Minnesota citizens but, no doubt, there is a charge for subscribers in Canada. Address: State Office Building, St. Paul, Minn.

C A N A D I A NATURE. This sparkling publication captures the the hearts of everyone interested in Nature, the outdoors, and conservation. The magazine, which is beauifully illustrated is published 5 times a year from 177 Jarvis St., Toronto 2. Subscription rate $\$ 1.50$ a year.

COUNTRY SIDE. English folk will enjoy reading the Journal of the British Empire Naturalists' Association. (Our Society is affiliated with the B.E.N.A.) It is a fascinating magazine published each alternate month and is devoted entirely to nature records and observations, written by naturalists in England and throughout the British Empire. Subscription rate 10 s. Write G. A. Hebditch, 92 Rydes Hill Road, Guildford, Surrey.

THE VICTORIA NATURALIST. A monthly Nature bulletin published by the Victoria Natural History Society. Deals mostly with ac- tivities of this progressive Society and with the observations, researches and opinions of its members. Subscription rate $\$ 2.00$, payable to Miss Margaret Kirby, 32 Marlborough St., Victoria, B.C.

THE CARDINAL. Quarterly bulletin of the Don Valley Conservation Association. In particular it is devoted to the conservation of wildlife of the Don Valley, north of Toronto. There will be numerous subjects pertaining also to every-day conservation which will be of great general interest. The first issue of The Cardinal appeared this spring. Write to the Don Valley Conservation Association, 22 Hillside Drive South, Toronto 6 .

THE WOOD DUCK is the official bulletin of the Hamilton Nature Club. It is published monthly from September to May. Its purpose is to aid in the study, appreciation and conservation of our nature, wild, and beautiful heritage, where members share their nature experiences. Subscription rate $\$ 1.00$ a year, payable to Mr. J. E. H. Martin, Ancaster, Ontario.

\title{
NOTICE TO CONTRIBUTORS
}

IN ORDER that as many of our members as possible may have an opportunity of having their nature records and observations printed it is suggested that any one article be limited to 650 words so that no story will be carried over to a second page. For those using a typewriter, two letter-length pages, double spaced is about right.

It is very often possible to cut down material considerably without affecting to any appreciable extent the story which is being told. Observation notes, consisting of 50,100 or 200 words are most welcome. Do not keep to yourself some interesting experience because you cannot write a printed page about it.

We would appreciate it very much if you submit sketches, cuttings from magazines, or photographs to illustrate your story. These may be reduced to any desirable size and will brighten the pages of the BLUE JAY.

Do not wait until the last month or week to send in material. Write it while the details are fresh in your memory and mail at once. Later, if something else of interest turns up, tell us about that too.

Too few record their botannical observations. Wild flowers are a fascinating study. Get better acquainted with them and record any unusual or interesting facts. If you do not know what a flower is, send us a specimen. In our next issue we will discuss those sent in, and name them.

Any ideas or suggestions that you may have, which will tend to improve the quality and set-up of our magazine will be most thankfully received. Iielp us to produce a better BLUE JAY. 